\title{
COMUNICAÇÃO
}

\section{MULTIPLICAÇÃO E ENRAIZAMENTO IN VITRO DEAMOREIRA-PRETA 'XAVANTE': EFEITO DA CONCENTRAÇÃO DE SAIS, DO TIPO DE EXPLANTE E DE CARVÃO ATIVADO NO MEIO DE CULTURA}

\author{
Blackberry 'Xavante' in vitro multiplication and rooting: salt concentrations effect, \\ explant type, and activated coal on culture medium
}

Luciane Nolasco Leitzke', Cláudia Roberta Damiani², Márcia Wulff Schuch³

\begin{abstract}
RESUMO
Atualmente, além da propagação tradicional, a micropropagação da amoreira-preta é considerada uma alternativa viável, com o intuito de obter-se plantas livres de vírus, geneticamente uniformes e em curto espaço de tempo. Objetivou-se, com este experimento, determinar o melhor tipo de explante e concentração de sais para a multiplicação in vitro e a melhor concentração de carvão ativado e de sais no meio de cultura, para o enraizamento in vitro de amoreira-preta 'Xavante'. O primeiro experimento constituiu-se de segmentos nodais caulinares com cerca de $1 \mathrm{~cm}$, oriundas do cultivo in vitro, inoculadas em quatro diferentes concentrações de meio MS, suplementada com 7,5 $\mu \mathrm{M}$ de BAP, $30 \mathrm{~g} \mathrm{~L}^{-1}$ de sacarose, $100 \mathrm{mg} \mathrm{L}^{-1}$ de mio-inositol e $6 \mathrm{~g} \mathrm{~L}^{-1}$ de ágar, e dois tipos de explante, totalizando 8 tratamentos. O segundo experimento constituiu-se de microestacas apicais, com cerca de 1 a $1,5 \mathrm{~cm}$ de comprimento, e duas folhas, inoculadas em três diferentes concentrações de meio MS, acrescido de $30 \mathrm{~g} \mathrm{~L}^{-1}$ de sacarose, $100 \mathrm{mg} \mathrm{L}^{-1}$ de mio-inositol e $6 \mathrm{~g} \mathrm{~L}^{-1}$ de ágar e suplementado com três concentrações de carvão ativado, totalizando nove tratamentos, com delineamento inteiramente casualizado. Pode-se concluir que o T1, ou seja, explante com folhas, na concentração de $125 \%$ de sais do meio MS foi mais eficiente, induzindo maior número de folhas, gemas, brotações e comprimento das brotações e que o uso de $75 \%$ de sais sem a suplementação de carvão ativado é o mais indicado para o enraizamento in vitro de amoreira-preta 'Xavante'.
\end{abstract}

Termos para indexação: Cultura de tecidos, pequenas frutas, Rubus sp.

\begin{abstract}
Besides the traditional propagation, blackberry micropropagation has currently been considered a feasible alternative, with the purpose of obtaining plants free from virus, genetically uniform and in the short run. The objective of this experiment was to determine the best explant type and the optimum in vitro multiplication salts concentration as well as to determine the activated coal and salts optimum concentrations in culture medium for. The first experiment constituted of nodal segments with $1 \mathrm{~cm}$, originated from of the in vitro cultivation, inoculated at four different MS medium concentrations, supplemented with $7.5 \mu \mathrm{M} \mathrm{BAP}, 30 \mathrm{~g} \mathrm{~L}^{-1}$ sucrose, $100 \mathrm{mg} \mathrm{L}^{-1}$ myo-inositol and $6 \mathrm{~g} \mathrm{~L}^{-1}$ agar, and with two types of explants, which totaled 8 treatments. The second experiment constituted of apex microcutting, having about 1 to $1.5 \mathrm{~cm}$ length, and two leaves were inoculated at three different concentrations of MS medium, added of $30 \mathrm{~g} \mathrm{~L}^{-1}$ sucrose, $100 \mathrm{mg} \mathrm{L}^{-1}$ myo-inositol and $6 \mathrm{~g} \mathrm{~L}^{-1}$ agar and supplemented with three different activated coal concentrations, totaling nine treatments. It can be inferred that $\mathrm{T} 1$, in other words, explants with leaves, were more efficient at $125 \%$ MS salt concentration on culture medium, thereby inducing larger number of leaves, buds, shoots and shoot length, and that the use of $75 \%$ salt concentration without activated coal is the most suitable one for the blackberry 'Xavante' in vitro rooting.
\end{abstract}

Index terms: Tissue culture, small fruits, Rubus sp.

(Recebido em 29 de agosto de 2007 e aprovado em 11 de junho de 2008)

A amoreira-preta é uma espécie cultivada nas regiões Sul e Sudeste do Brasil. A técnica de micropropagação apresenta diversas vantagens em relação aos métodos tradicionalmente utilizados na propagação de amoreira-preta, especialmente quanto à maior sanidade das mudas. Uma importante etapa da micropropagação, além da multiplicação, refere-se ao enraizamento das microestacas obtidas. $\mathrm{O}$ enraizamento é uma etapa que define o resultado final da micropropagação, e consiste na formação de raízes adventícias na base das microestacas.

\footnotetext{
${ }^{1}$ Engenheira Agrônoma, Doutoranda em Agronomia - Departamento de Fitotecnia - Faculdade de Agronomia Eliseu Maciel/FAEM - Universidade Federal de Pelotas/UFPel - Rua Santa Cruz, 2096, apto 201 - Centro - 96015-710 - Pelotas, RS - lucianeleitzke@gmail.com

'Bióloga, Doutora em Biotecnologia Molecula - Departamento de Fitotecnia - Faculdade de Agronomia Eliseu Maciel/FAEM - Universidade Federal de Pelotas/UFPel - Rua Dom Pedro II, 364, apto 201 ${ }^{\text {a }}$ - Centro - 96010-300 - Pelotas, RS - claudami2004@yahoo.com.br - Bolsista CNPq ${ }^{3}$ Engenheira Agrônoma, Doutora, Professora - Departamento de Fitotecnia - Faculdade de Agronomia Eliseu Maciel/FAEM - Universidade Federal de Pelotas/UFPel - Cx. P. 354 - 96010-900 - Pelotas, RS - marciaws@ufpel.tche.br
} 
Vários autores têm relatado a possibilidade de reduzir a concentração de sais do meio MS, para diversas espécies, visando o melhor desenvolvimento das plantas e redução nos custos (GEORGE \& SHERRINGTON, 1984). Paiva et al. (1997) utilizaram 50\% dos sais do meio MS, obtendo um bom desenvolvimento in vitro de gloxínia. Concentrações de sais no meio básico MS reduzidas à 1/2, 1/3 ou 1/4 possibilitaram melhor enraizamento in vitro de amoreirapreta, cultivar Cainguangue (DANTAS et al., 2000).

Dentre os antioxidantes usados, destaca-se o carvão ativado, um componente que tem sido freqüentemente adicionado aos meios de cultura de tecidos vegetais com sucesso (WINKLE et al., 2003), mas de cujos efeitos ainda não se possui bom entendimento. Espécies lenhosas são beneficiadas com o uso de carvão ativado quando enraizadas in vitro. Dotado de uma alta capacidade de adsorção, essa substância tem a propriedade de modificar a composição dos meios de cultura, adsorvendo substâncias promotoras de enraizamento e também substâncias tóxicas, fenóis e/ou quinonas, produzidas durante a autoclavagem ou liberadas de explantes, cujos tecidos sofreram injúrias. Outra propriedade atribuída ao carvão ativado, como sendo benéfica ao processo de enraizamento, é quanto à redução da intensidade de luz na região de formação de raízes, porém, concentrações elevadas de carvão ativado podem até mesmo impedir o processo de enraizamento (ASSIS \& TEIXEIRA, 1998).

Objetivou-se, com este trabalho, determinar o melhor tipo de explante e a melhor concentração de sais do meio de cultivo para a multiplicação in vitro, e determinar as melhores concentrações de carvão ativado e de sais do meio de cultivo para o enraizamento in vitro de amoreirapreta 'Xavante'.

Este trabalho foi dividido em dois experimentos:

$1^{\mathbf{0}}$ Experimento: Multiplicação in vitro de amoreirapreta 'Xavante';

$2^{\mathbf{0}}$ Experimento: Enraizamento in vitro de amoreirapreta 'Xavante'.

Os trabalhos foram conduzidos no Laboratório de Micropropagação de Plantas Frutíferas, do Departamento de Fitotecnia da Faculdade de Agronomia Eliseu Maciel (FAEM), da Universidade Federal de Pelotas (UFPel), em Pelotas, RS.

Para o primeiro experimento, utilizaram-se segmentos nodais caulinares, com duas gemas e o ápice excisado, de cerca de $1 \mathrm{~cm}$, oriundas do cultivo in vitro de amoreira-preta 'Xavante'. Os fatores estudados foram: concentração dos sais do meio de cultura $(50,75,100$ e $125 \%$ ) e tipo de explante $\mathrm{T} 1=$ explante com folha e $\mathrm{T} 2=$ explantes sem folhas, no delineamento inteiramente casualizado, em esquema fatorial 4X2, totalizando 8 tratamentos com quatro repetições, sendo cada repetição constituída por um frasco com cinco explantes. Utilizou-se para o experimento, meio MS (MURASHIGE \& SKOOG, 1962) acrescido de 7,5 $\mu \mathrm{M}$ de BAP, concentração essa fixada a partir dos resultados obtidos com experimentos preliminares, $30 \mathrm{~g} \mathrm{~L}^{-1}$ de sacarose, $100 \mathrm{mg} \mathrm{L}^{-1}$ de mio-inositol e $6 \mathrm{~g} \mathrm{~L}^{-1}$ de ágar, sendo o $\mathrm{pH}$ ajustado para 5,8, antes da inclusão do ágar e, posteriormente, autoclavado a $121^{\circ} \mathrm{C}$ e 1,5 atm por 20 minutos.

Após a inoculação, os explantes foram transferidos para a sala de crescimento com temperatura de $25 \pm 2^{\circ} \mathrm{C}$, densidade de fluxo de fótons de $27 \mu \mathrm{mol} \mathrm{m}^{-2} \mathrm{~s}^{-1}$ e fotoperíodo de 16 horas. Após 30 dias foi avaliado o número de brotações, gemas e folhas por explante e o comprimento das brotações.

Para o segundo experimento foram utilizados microestacas apicais com duas folhas, de cerca de 1 a 1,5 $\mathrm{cm}$, obtido de plantas in vitro de amoreira-preta 'Xavante'. Os fatores estudados foram: concentração dos sais do meio de cultura $(50,75$ e $100 \%)$ e concentração de carvão ativado no meio de cultura $\left(0 ; 10\right.$ e $\left.20 \mathrm{~g} \mathrm{~L}^{-1}\right)$, no delineamento inteiramente casualizado, em esquema fatorial $3 \mathrm{X} 3$, totalizando nove tratamentos com quatro repetições, sendo cada repetição constituída por um frasco com cinco explantes. Utilizou-se, para o experimento, meio MS acrescido de $3 \mu \mathrm{M}$ de AIB, concentração essa fixada a partir dos resultados obtidos com experimentos preliminares, $30 \mathrm{~g} \mathrm{~L}^{-1}$ de sacarose, $100 \mathrm{mg} \mathrm{L}^{-1}$ de mio-inositol e $6 \mathrm{~g} \mathrm{~L}^{-1}$ de ágar, sendo o $\mathrm{pH}$ ajustado para 5,8, antes da inclusão do carvão ativado e do ágar e, posteriormente autoclavado a $121^{\circ} \mathrm{C}$ e 1,5 atm por 20 minutos.

Após a inoculação, os explantes foram transferidos para sala de crescimento e mantidos à temperatura de $25 \pm$ $2{ }^{\circ} \mathrm{C}$, densidade de fluxo de fótons de $27 \mu \mathrm{mol} \mathrm{m} \mathrm{m}^{-2} \mathrm{~s}^{-1} \mathrm{e}$ fotoperíodo de 16 horas.

Após 30 dias foram avaliadas as variáveis porcentagem de enraizamento, número médio de raízes e comprimento das raízes. Os dados dos dois experimentos foram submetidos à análise de variância e as médias dos tratamentos comparadas, estatisticamente, pelo teste de Duncan, através do programa estatístico WinStat (MACHADO \& CONCEIÇÃO, 2002).

Experimento 1: Multiplicação in vitro de amoreira-preta 'Xavante'.

Através da análise de variância pôde-se observar efeito isolado do fator concentração de sais no meio de cultura, para as variáveis número médio de gemas, número médio de brotações e comprimento médio das brotações. Nas figuras 1, 2 e 3 observa-se um comportamento linear ascendente para todas as variáveis citadas. 


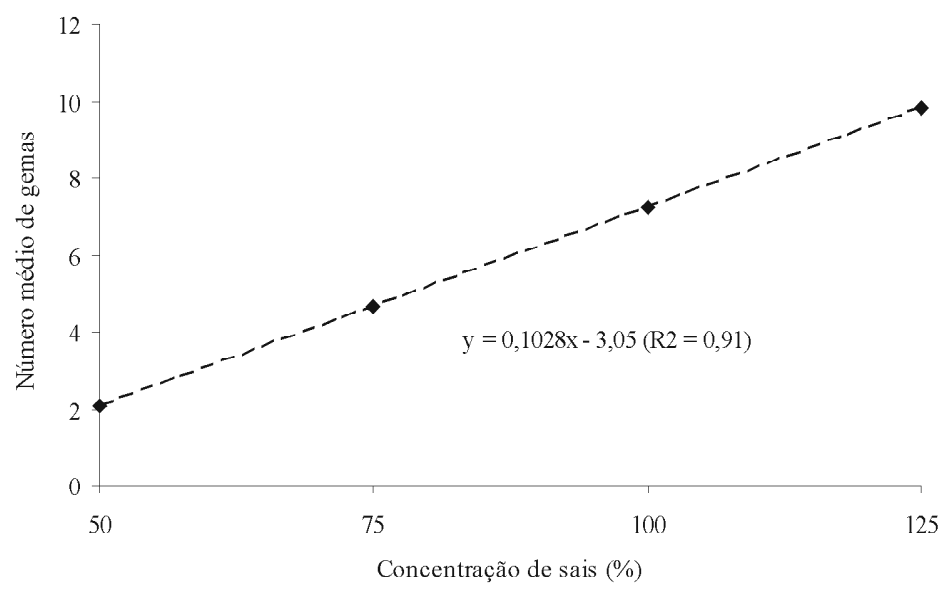

Figura 1 - Número médio de gemas por brotação de amoreira-preta 'Xavante', em função da concentração de sais no meio de cultura. Pelotas, RS, 2007.

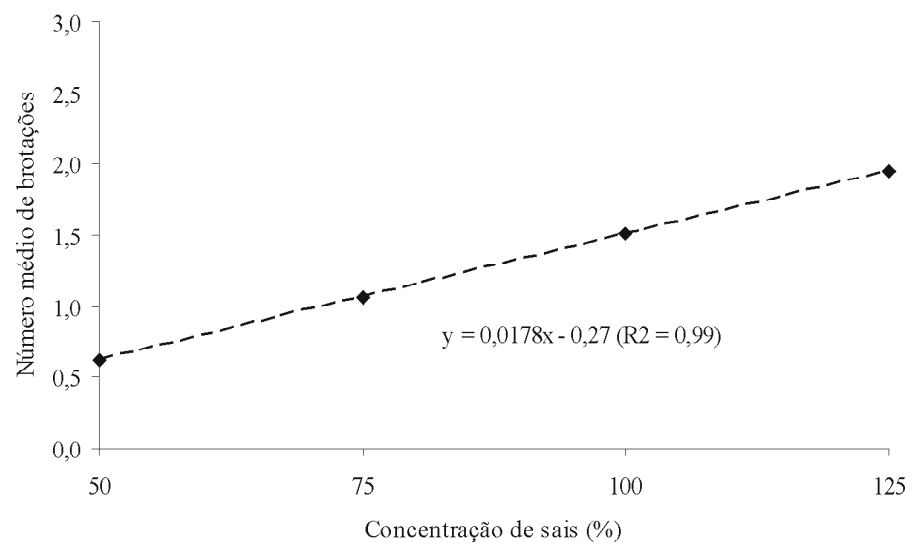

Figura 2 - Número médio de brotações por explante de amoreira-preta 'Xavante' em função da concentração de sais no meio de cultura. Pelotas, RS, 2007.

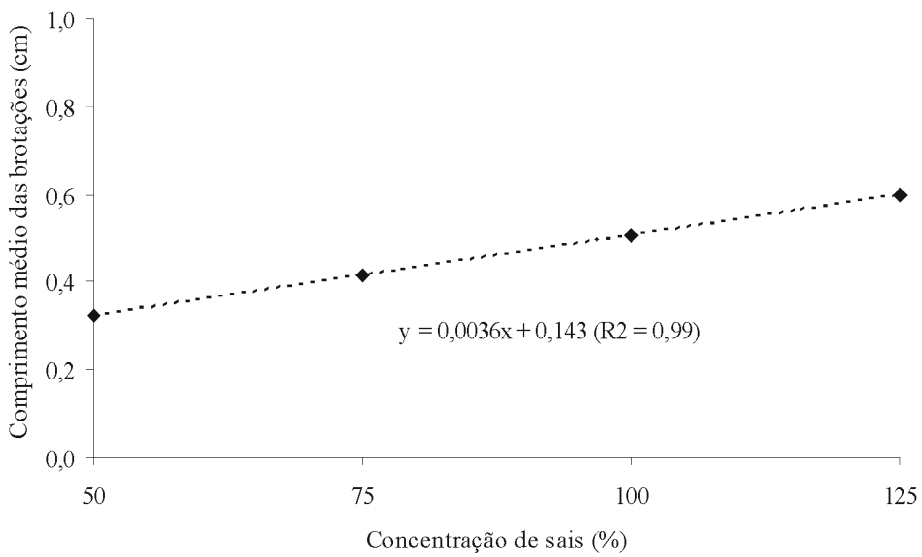

Figura 3 - Comprimento médio das brotações de amoreira-preta 'Xavante', em função da concentração de sais no meio de cultura. Pelotas, RS, 2007. 
Em relação ao número de brotos formados por explante, os valores obtidos foram semelhantes aos de Villa et al. (2005), onde o número de brotos de amoreirapreta 'Ébano' foi estimulado pelo aumento da concentração de sais de MS, com maior número de brotos observado em meio MS $150 \%$, porém no que se refere à variável comprimento de broto foi observado melhor resultado $(2,83 \mathrm{~cm})$ em meio MS 50\%, com 0,5 $\mathrm{mg} . \mathrm{L}^{-1}$ de BAP; já na ausência dessa citocinina no meio MS $150 \%$, houve um maior comprimento de brotações $(3,79 \mathrm{~cm})$, concordando com os resultados obtidos nesse trabalho.

Quando comparados a outras espécies, os resultados obtidos foram próximos aos de Forni \& Pasqual (1996) e Naves (2001) que observaram aumento no tamanho dos brotos quando a concentração de sais era aumentada até $100 \%$, em bromélia imperial e café, respectivamente; porém discordam de Preece (1995) o qual afirma que meios baseados em formulações básicas diluídas têm possibilitado melhores resultados para a multiplicação das diversas espécies, estando mais de acordo com Zimmerman (1988) o qual afirma que as necessidades das cultivares dentro de uma mesma espécie são diferentes, havendo necessidade de modificação do meio e concentração de citocinina.

Castro et al. (2003), estudando a multiplicação in vitro de Limonium brasiliensis A. Heller, verificaram que o meio MS e 50\% MS, sem a presença de BAP, revelou-se significativo para a variável número médio de brotações, por explante.
Dzazio et al. (2002), concluiram que o porta-enxerto de videira '420'-A pode ser multiplicado em meio MS1/2, ou seja, concentração dos sais reduzidos em $50 \%$ isento de reguladores de crescimento.

Já para a variável número médio de folhas houve efeito significativo da interação entre concentrações de sais e o tipo de explante. Na figura 4, observa-se que o número médio de folhas mostrou um comportamento quadrático quando se utilizou o T2 $=$ explante sem folhas, com um aumento do número de folhas até a concentração de $107 \%$ de sais; logo, ocorre um decréscimo da variável analisada, já para o T1= explante com folhas, a tendência foi linear ascendente, com o aumento da concentração de sais houve um aumento do número de folhas de amoreira-preta 'Xavante'.

Para as variáveis número médio de gemas, de brotações e comprimento das brotações, houve diferença significativa para o fator tipo de explante. $\mathrm{Na}$ tabela 1, observamos que explantes contendo folhas apresentaram melhores resultados. O número de folhas tem influência principalmente na velocidade de enraizamento e no número de raízes formadas. Cresswell \& Fossard (1974), citados por Assis \& Teixeira (1998), testaram o efeito da área foliar no enraizamento de explantes de Eucaliptus grandis W. Hill. Foram deixadas duas folhas, uma folha, duas meias-folhas ou nenhuma folha por explante. Houve tendência de maior desenvolvimento de gemas e de sistemas radiculares em explante com maior área foliar.

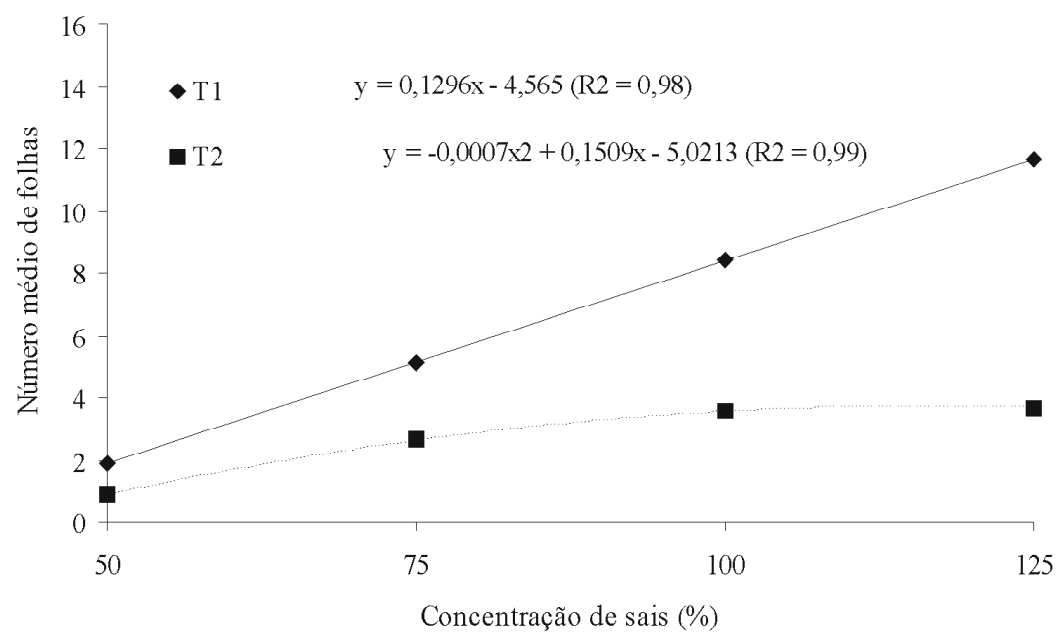

Figura 4 - Número médio de folhas de amoreira-preta 'Xavante', em função da concentração de sais no meio de cultura, utilizando-se explantes com folhas (T1) e sem folhas (T2). Pelotas, RS, 2007. 
Experimento 2: Enraizamento in vitro de amoreira-preta 'Xavante'.

Houve efeito significativo da interação entre concentrações de sais e de carvão ativado no meio de cultura, para a variável número médio de raízes. Na figura 5 , observa-se que o número de raízes teve um comportamento quadrático, com $75 \%$ de sais no meio de cultura, houve uma redução do número médio de raízes até a concentração de $14,8 \mathrm{~g}$ de carvão ativado e, a partir desse valor, observa-se um aumento do número médio de raízes. Quanto à utilização de $100 \%$, de sais no meio de cultura teve também, um comportamento quadrático, onde o maior número médio de raízes foi observado com $5,8 \mathrm{~g}$ de carvão ativado. Já para a concentração de $50 \%$ de sais no meio de cultura observa-se um comportamento linear descendente, com aumento na concentração de carvão ativado no meio houve uma redução no número de raízes de amoreira-preta 'Xavante', concordando com Assis \& Teixeira (1998), que revelam que concentração elevada de carvão ativado, para algumas espécies, pode afetar negativamente o processo de enraizamento. Dzazio et al. (2002) encontraram maior número de raízes $(1,97)$ e porcentagem de enraizamento no meio MS/2 (concentração dos sais diluídos em 50\%) sem carvão ativado no meio em porta-enxerto de videira '420A'. Costa et al. (2006) verificaram que brotações cultivadas em meio desprovido de carvão ativado apresentaram decréscimo no número de raízes, para a característica número de raízes, confirmando a teoria de Diniz et al. (2003) a qual a suplementação do meio com carvão ativado favoreceu o enraizamento das brotações, independentemente das concentrações de N6-BAP testadas. Villegas (1990), citado por Calvete et al. (2002), verificou que a utilização do carvão ativado causou efeito benéfico na estimulação da rizogênese in vitro de morangueiro, em relação ao tratamento à testemunha (ausência de carvão ativado).

Para a porcentagem de enraizamento e comprimento médio das raízes de amoreira-preta 'Xavante', observouse uma tendência linear descendente, para a utilização de carvão ativado no meio de cultura, independente da concentração de sais. Através do aumento da concentração de carvão ativado, houve uma redução na porcentagem de enraizamento e no comprimento médio das raízes (Figura 6 e 7).

Tabela 1 - Número médio de gemas, número médio de brotações e comprimento médio das brotações de amoreira-preta 'Xavante', em função do tipo de explante utilizado (T1= explante com folha; T2 = explante sem folha). Pelotas, RS, 2007.

\begin{tabular}{cccc}
\hline Tipo de explante & Número médio de gemas & $\begin{array}{c}\text { Número médio de } \\
\text { brotações }\end{array}$ & $\begin{array}{c}\text { Comprimento médio das } \\
\text { brotações }\end{array}$ \\
\hline T1 & $8,3 \mathrm{a}$ & $1,7 \mathrm{a}$ & $0,63 \mathrm{a}$ \\
$\mathrm{T} 2$ & $3,6 \mathrm{~b}$ & $0,88 \mathrm{~b}$ & $0,29 \mathrm{~b}$ \\
\hline $\mathrm{CV}(\%)$ & 26,09 & 20,03 & 50,62
\end{tabular}

* Médias seguidas da mesma letra minúscula nas colunas não diferem entre si pelo teste de Duncan, ao nível de 5\%.

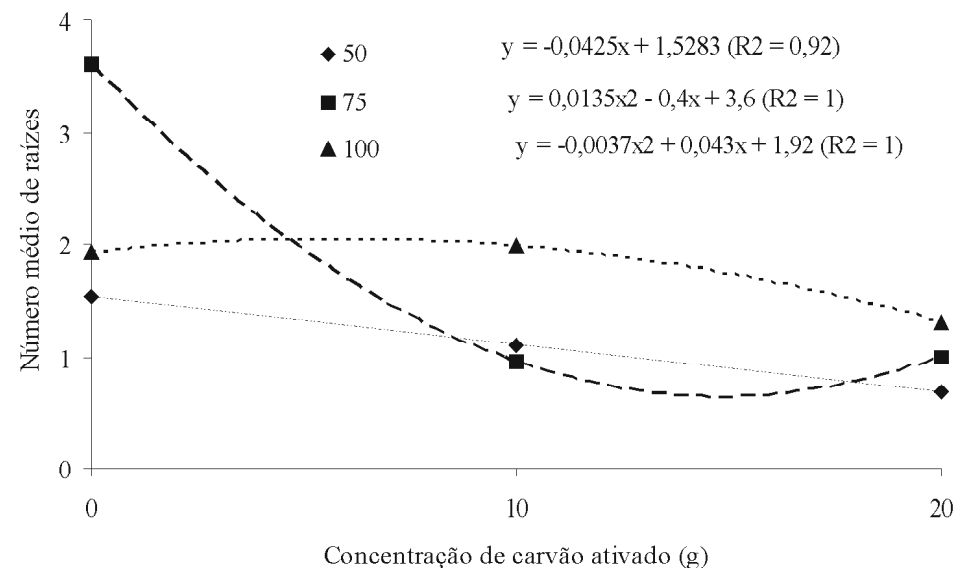

Figura 5 - Número médio de raízes de amoreira-preta 'Xavante', em função de diferentes concentrações de sais e da concentração de carvão ativado no meio de cultura. Pelotas, RS, 2007. 


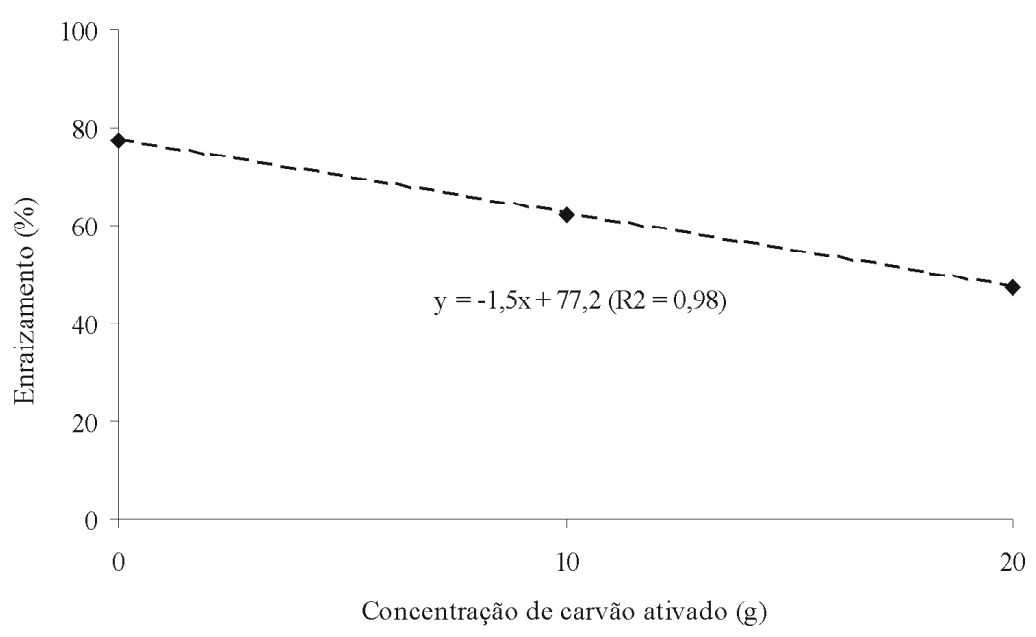

Figura 6 - Porcentagem de enraizamento de amoreira-preta 'Xavante', em função da concentração de carvão ativado no meio de cultura. Pelotas, RS, 2007.

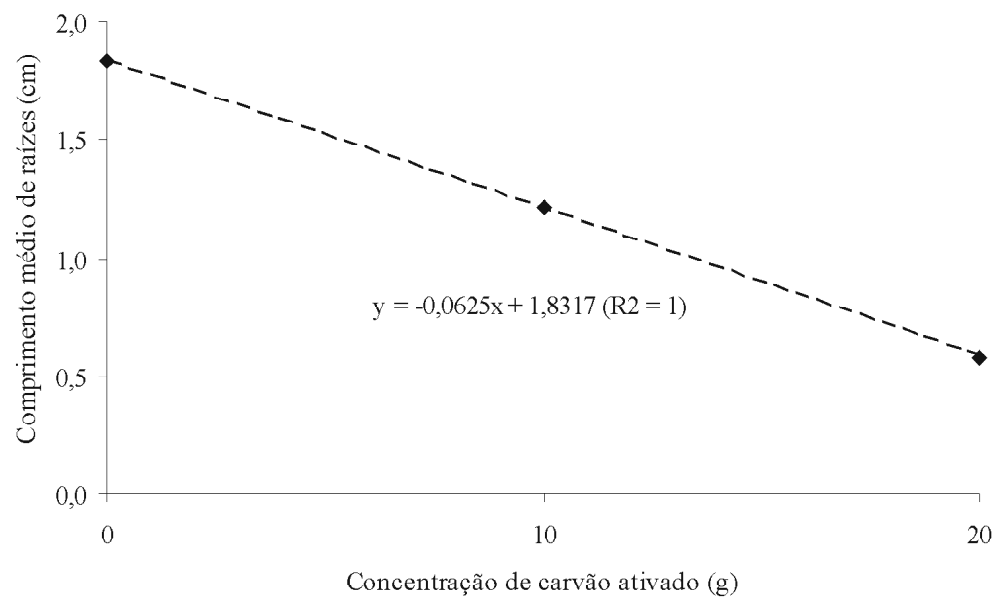

Figura 7 - Comprimento médio das raízes de amoreira-preta 'Xavante', em função da concentração de carvão ativado no meio de cultura. Pelotas, RS, 2007.

Pelos resultados obtidos, verifica-se que, para o enraizamento in vitro de amoreira-preta 'Xavante', a utilização de carvão ativado no meio de cultura, não favorece o enraizamento, nessas concentrações avaliadas. De acordo com Grattapaglia \& Machado (1990), o carvão ativado em concentrações de 1 a 20 g L${ }^{1}$ pode ser benéfico em alguns casos. Fisicamente, ele simula a condição de escuro, no qual as raízes normalmente se desenvolvem melhor. Quimicamente, o carvão ativado tem efeito adsorvente, retendo parte de todos os elementos que compõem o meio. Entretanto, a adição de carvão ao meio de cultivo nem sempre tem se mostrado vantajosa. Nicoloso et al. (2001) verificaram que a porcentagem de enraizamento em Pfaffia glomerata (Spreng.) Pedersen não foi influenciada pela presença de carvão ativado no meio de cultura, resultado semelhante foi encontrado por Erig et al. (2004), trabalhando com pereira 'Carrick'. Os autores verificaram que a porcentagem de enraizamento foi nula, com a utilização de $1 \mathrm{~g} \mathrm{~L}^{-1}$ de carvão ativado no meio de cultura. Já Santana et al. (2005), avaliando a influência do AIB e do carvão ativado em brotações de Annona glabra L., verificaram efeitos positivos da adição do carvão sobre o número de raízes, número de raízes secundárias, comprimento da maior raiz, porcentagem de enraizamento e peso seco das raízes. 
Conclui-se que os explantes mantidos com folhas inoculados em meio MS com, pelo menos, $125 \%$ dos seus sais é a melhor combinação para multiplicação in vitro de amoreira-preta 'Xavante'.

Para o experimento de enraizamento pôde-se concluir que o tratamento com $75 \%$ de sais no meio de cultura, na ausência de carvão ativado é o mais indicado para o enraizamento in vitro de amoreira-preta 'Xavante', promovendo maior porcentual, a formação de maior número médio de raízes e maior comprimento médio das raízes.

\section{AGRADECIMENTOS}

Este trabalho foi desenvolvido com o apoio do Ministério da Ciência e Tecnologia (MCT); Conselho Nacional de Desenvolvimento Científico e Tecnológico (CNPq); Fundação de Amparo à Pesquisa do Estado do Rio Grande do Sul (FAPERGS).

\section{REFERÊNCIAS BIBLIOGRÁFICAS}

ASSIS, T. F.; TEIXEIRA, S. L. Enraizamento de plantas lenhosas. In: TORRES, A. C.; CALDAS, L. S.; BUSO, J. A. Cultura de tecidos e transformação genética de plantas. Brasília, DF: Embrapa-SPI/Embrapa-CNPH, 1998. v. 1, p. 183-260.

CALVETE, E. O.; KÄMPF, A. N.; SUZIN, M. Concentração de sacarose no enraizamento in vitro de morangueiro. Horticultura Brasileira, Brasília, v. 20, n. 2, p. 186-191, jun. 2002.

CASTRO, K. G. da S. et al. Multiplicação in vitro de Limonium brasiliensis (BOISS.) Kuntze: diferentes concentrações de BAP e sais minerais no meio de cultura. In: CONGRESSO BRASILEIRO DE FLORICULTURA E PLANTAS ORNAMENTAIS, 14.; CONGRESSO BRASILEIRO DE CULTURA DE TECIDOS DE PLANTAS, 1., 2003, Lavras, MG. Anais... Lavras: UFLA, 2003. p. 132.

COSTA, F. H. S.; PEREIRA, J. E. S.; PEREIRA, M. A. A.; OLIVEIRA, J. P. Efeito da interação entre carvão ativado e N6 - benzilaminopurina na propagação in vitro de bananeira, cv. Grand Naine (AAA). Revista Brasileira de Fruticultura, Jaboticabal, v. 28, n. 2, p. 280-283, ago. 2006.

DANTAS, M. C. A. et al. Enraizamento in vitro da amoreira-preta (Rubus sp.), cultivar Caigangue. Agropecuária de Clima Temperado, Pelotas, v. 3, n. 2, p. 123-130, 2000.
DINIZ, J. D. N.; ALMEIDA, J. L.; TEIXEIRA, A. L. de A.; GOMES, E. S.; HERNANDEZ, F. F. F. Ácido giberélico (GA3) e 6-Benzilaminopurina (BAP) no crescimento in vitro de Macela [Egletes viscosa (L.) Less.]. Ciência e Agrotecnologia, Lavras, v. 27, n. 4, p. 934-938, 2003.

DZAZIO, P. M. et al. Micropropagação do porta-enxerto de videira '420-A'. Revista Brasileira de Fruticultura, Jaboticabal, v. 24, n. 3, p. 759-764, 2002.

ERIG, A. C. et al. Enraizamento in vitro de pereira (Pyrus communis L.) ev. Carrick. Ciência Rural, Santa Maria, v. 34, n. 1, jan./fev. 2004.

FORNI, R. C.; PASQUAL, M. Influência da citocinina BAP e concentrações dos componentes do meio 'MS' na micropropagação do café 'Catuaí'. Ciência e Agrotecnologia, Lavras, v. 20, n. 4, p. 468-474, 1996.

GEORGE, E. F.; SHERRINGTON, P. D. Plant propagation by tissue culture. Eversley: Exegetics, 1984. 709 p.

GRATTAPAGLIA, D.; MACHADO, M. A.

Micropropagação. In: TORRES, A. C.; CALDAS, L. S. Técnicas e aplicações da cultura de tecidos de plantas. Brasília, DF: ABCTP/Embrapa-CNPH, 1990. p. 99-169, 433 p.

MACHADO, A.; CONCEIÇÃO, A. R. Programa estatístico WinStat: sistema de análise estatístico para Windows. Versão 2.0. Pelotas, RS: Windows, 2002.

MURASHIGE, T.; SKOOG, F. A revised medium for rapid growth and biossay with tobacco tissue cultures. Physiologia Plantarum, Cepenhagen, v. 15, p. 473-497, 1962.

NAVES, V. C. Propagação in vitro de bromélia imperial [Ancantarea imperialis (Carriére) Harms]. 2001. 64 p. Dissertação (Mestrado em Fitotecnia) - Universidade Federal de Lavras, Lavras, 2001.

NICOLOSO, F. T. et al. Micropropagação do Ginseng Brasileiro [Pfaffia glomerata (Spreng.) Pedersen].

Revista Brasileira de Plantas Medicinais, Botucatu, v. 3, n. 2, p. 11-18, 2001.

PAIVA, P. D. O. et al. Propagação in vitro de gloxínia. Revista Brasileira de Horticultura Ornamental, Campinas, v. 3, n. 2, p. 29-41, 1997. 
PREECE, J. E. Can nutrient salts partially substitute for plant growth regulators? Plant, Tissue Culture and Bioteechnology, Rehovot, v. 1, n. 1, p. 26-37, 1995.

SANTANA, J. R. F.; BRITO, A. L.; PAIVA, R. Influência do AIB e do carvão ativado no enraizamento, crescimento e desenvolvimento de microplantas de Annona glabra L. In: CONGRESSO BRASILEIRO DE OLERICULTURA, 45.; CONGRESSO BRASILEIRO DE FLORICULTURA E PLANTAS ORNAMENTAIS, 15; CONGRESSO BRASILEIRO DE CULTURA DE TECIDOS DE PLANTAS, 2., 2005, Fortaleza, CD. Anais... Fortaleza, 2005. CD-ROM.
VILLA, F. et al. Multiplicação in vitro da amoreira-preta 'Ébano' em diferentes concentrações de meio MS e BAP. Ciência e Agrotecnologia, Lavras, v. 29, n. 3, p. 582-589, maio/jun. 2005.

WINKLE, S. van; JOHNSON, S.; PULLMAN, G. S. The impact of gelrite and activated carbon on the elemental composition of plant tissue culture media. Plant Cell Report, New York, v. 21, p. 1175-1182, 2003.

ZIMMERMAN, R. H. Cultivo de tejidos. In: MOORE, J. N.; JANICK, J. Métodos genotécnicos en frutales. México: AGT, 1988. p. 167-182. 